(2) That a commisaion, including representatives of the magistracy, the higher penitentiary administration, and the medical element, be empowered to organize this inquiry, having for its objects :-

(a) Accused persons suspected of heing insane.

(b) Persons who, being admittelly insane, have committed any crime whatsoever.

(c) Great criminals, and old offenders.

(d) Prisoners who during their imprisonment are found to be insane.

On the proposition of Professor BRNEnIKT, the Congress expressed the wish that criminal clinios might be established.

The Prrsidrart, in closing the Congress, thanked the foreign savants for their attendance. He gave a summary of the results of the discussions, and in. vited the members to take part in the various excursions.

M. BENEDIKT, on behalf of the foreign members, tha nked the Organising Committee of the Congress for the trouble they had taken. "We leave Belgium," he added, "convinced that every country which possesses a medical body like that which we have met here may consider itself fortunate."

\title{
BELGLAN ASYLOMS.
}

We have already in another section of the Journal related at some length our experience at Gheel, which constitutes for most mental physicians visiting Bolgium the main object of interest.

Of the former, we may, however, say that there is much in their management and condition which reflects oredit on those who are in charge. Several exist, no doubt, which from their age, the character of their government, and their locality, call for reform and adaptation to modern requirements. At Antwerp itself, the asylum of St. Roch is quite behind the times, and no one disputes that a new asylum ought to be erected outside the town. A praiseworthy attempt is made to employ the patients within the narrow limit which the building affords.

At Bruges there is room for improvement in the asylums, but it should be men. tioned to the credit of the Hospice Saint Dominique that there is not only a very fine garden connected with it in the town, but some miles distant a farm to which patients are conveyed daily to work. There is also one associated with the Hospice Saint Julien. At Saint Dominique, the Director, M. Soleil, is active and humane, and the asvlum is visited by Dr. Valcke, who obligingly took us to 800 it. To the Visiting Physicians to Saint Julien, Drs. F. Van den Abeele and Moulaert, we are indebted for facilities of visitation.

At Mons, the asylum superintended by the energetio and acoomplished physician, M. Semsl, was inspected with interest, and every facility afforded for seoing the whole establishment. Here, as in some other Belgian asylums, we might be allowed to doubt whether the influence acquired by the "Sisters" is not greater than it should be, although no doubt less at Mons than in those institutions where there is no resident medical authority. Here, as elsewhere, the contrast is somewhat striking between Belgian and English practice in the matter of non-restraint to which M. Semal has not jet become a convert. The accom. modation provided for many of the higher class patients was exceedingly good in this asylum, and the charges would in England be considered very moderate.

M. Lents superintends with much ability the new asylum at Tournai which has been built at great expense, and with careful consideration in regard to construction. An excellent model of it, as well as of a seclusion room prior and subsequent to 1850, with its unhappy occupant, was exhibited at the Exposition at Antwerp. The asylum at Tournai extorts from the visitor soarcely anything but praise, and if the Belgian authorities are to be congratulated on the care and expenditure lavished upon the building, they are still more so for their choice of co excellent an administrator as M. Lentz. Were we to indulge in any criticism, it would be in a mere point of detail-the arrangement adopted in regard to the 
closing of the ponderous metal shutters of the seclusion rooms by an apparatus outside in such a manner as can hardly fail to terrify by its unearthly noise the inhabitant of the cell, who would be only too likely to believe himself located in certain regions from which the asylum in other respects is as far as possible removed.

At Ghent, the Hospice-Guislain recalls a great mental physician of whom Belgium is justly proud, and whom those connected with the insane in other countries no less esteem for his writings and for the practical work done by him at this institution where $M$. Ingels is his worthy successor. We are glad to know that the project of erecting a statue to Guislain is progressing, and will be probably carried into effect next summer. At this institution we were particularly pleased with the amount of work done in the workshops, and especially at the loom. The school for idiots is adnirable. One of them, aged 7, presented a remarkable example of microcephalus, but displayed great agility and a certain kind of intelligence. The dimensions of the head were kindly taken for us at the time by M. Jules Morel, of Ghent, to whom members of the Congress were so greatly indebted for his unfailing help and courtesy.

The institution for the insane at Cortenberghe, near Brussels, called Hospice Saint Joseph, was visited. It is under the charge of the same religious orderScurs de la Miséricorde de Jésus-as St. Julien at Bruges and Saint George's Retreat, Burgess Hill. Sœur Ambroisine showed us over the institution with great courtesy. The cleanliness of the beds and rooms throughout the establishment, not excluding those for the dirty patients, was most marked, and reflected great credit upon those responsible for their condition, especially as the visit made one Sunday afternoon was totally unexpected. No patient was in seclusion, but many were sitting on benches in large rooms with their arms confined by long sleeves fastened behind in the asual way.

Our visits to the Belgian asylums afforded us much interest, and we must here acknowledge the courtesy and hospitality uniformly extended to us by those in charge. The latter may be assured of a friendly welcome from their English confrères whenever they visit Britain.

\section{THE CURABILITY OF INSANITY.}

Dr. Pliny Earle read an interesting paper on this question before the $\Delta$ seociation of Medical Superintendents of American Institutions for the Insane, on retiring from office as its President at Saratoga, N.Y., last summer. He returns to a subject which he has made his own by the large amount of labour he has expended upon it. His views, so far as they have hitherto been expressed, are so well-known in this country that it is unnecessary to repeat them. The present paper shows the actual results of treatment in a number of institutions, American and otherwise, brought down to a later date than that of former essays.

First, as to British asylums; a table is given of 23 asylums, the recoveries being arranged in accordance with the well-known table showing the duration of the attack and the recoveries, the results being as follows :-

1st class (first attack, less than three months' duration); the admissions were 8,316 ; recoveries, 4,051 ; per cent. of recoveries, $48 \cdot 71$. 2nd class (first attack, 3 to 12 months' duration) ; admissions, 2,613; recoveries, 764 ; per cent. of recoveries, 29.24. 3rd class (not first attack, less than 12 months' duration); admissions, 4,768; recoveries, 2,640 ; per cent. of recoveries, $55 \cdot 37$. The union of the first two classes gives all cases of first attack, and of less duration than one year. Of these the admissions were 10,929 , and the recoveries 4,815 , or 44.06 per cent. The percentage of recoveries in the 3rd elass is in accordance with Dr. Earle's experience, that recovery takes place in a less proportion of cases of first attack than in cases subsequent to the first. This was shown in the report of the Northampton Lanatic Hospital for 1880 . By throwing together the three classes, containing, as these do, cases of less than a jear's duration, 